\title{
Corrigendum: lonizing Particle Radiation as a Modulator of Endogenous Bone Marrow Cell Reprogramming: Implications for Hematological Cancers
}

\author{
Sujatha Muralidharan ${ }^{1}$, Sharath P. Sasi ${ }^{2}$, Maria A. Zuriaga ${ }^{1}$, Karen K. Hirschi ${ }^{3}$, Christopher \\ D. Porada ${ }^{4}$, Matthew A. Coleman ${ }^{5,6}$, Kenneth X. Walsh ${ }^{1}$, Xinhua Yan ${ }^{2,7}$ and \\ David A. Goukassian ${ }^{1,2,7 *}$ \\ ${ }^{1}$ Whitaker Cardiovascular Institute, Boston University School of Medicine, Boston, MA, USA, ${ }^{2}$ Cardiovascular Research \\ Center, GeneSys Research Institute, Boston, MA, USA, ${ }^{3}$ Yale Cardiovascular Research Center, Yale School of Medicine, \\ New Haven, CT, USA, ${ }^{4}$ Wake Forest Institute for Regenerative Medicine, Wake Forest School of Medicine, Winston-Salem, \\ NC, USA, ${ }^{5}$ Radiation Oncology, School of Medicine, University of California Davis, Sacramento, CA, USA, ${ }^{6}$ Lawrence \\ Livermore National Laboratory, Livermore, CA, USA, ${ }^{7}$ Tufts University School of Medicine, Boston, MA, USA
}

Keywords: progenitors, endogenous reprogramming, hematological cancer, radiation, HSC

A corrigendum on

\section{OPEN ACCESS}

Edited and Reviewed by: Marco Durante,

GSI Helmholtzzentrum für Schwerionenforschung, Germany

*Correspondence:

David A. Goukassian david.goukassian@tufts.edu, dgoukass@bu.edu

Specialty section: This article was submitted to Radiation Oncology, a section of the journal Frontiers in Oncology

Received: 29 October 2015 Accepted: 05 November 2015 Published: 25 November 2015

Citation: Muralidharan S, Sasi SP, Zuriaga MA, Hirschi KK, Porada CD,

Coleman MA, Walsh KX, Yan X and Goukassian DA (2015) Corrigendum: Ionizing Particle Radiation as a Modulator of Endogenous Bone Marrow Cell Reprogramming: Implications for Hematological Cancers.

Front. Oncol. 5:255. doi: 10.3389/fonc.2015.00255
Ionizing Particle Radiation as a Modulator of Endogenous Bone Marrow Cell Reprogramming: Implications for Hematological Cancers

by Muralidharan S, Sasi SP, Zuriaga MA, Hirschi KK, Porada CD, Coleman MA, et al. Front Oncol (2015) 5:231. doi: 10.3389/ fonc. 2015.00231

In the paper titled "Ionizing Particle Radiation as a Modulator of Endogenous Bone Marrow Cell Reprogramming: Implications for Hematological Cancers," there was secretarial error made at our end in "Figure 1," which should be corrected. At some point of the submission in Figure 1, A and B were disarranged in the slide. No other correction is needed as the text and figure legends are correct.

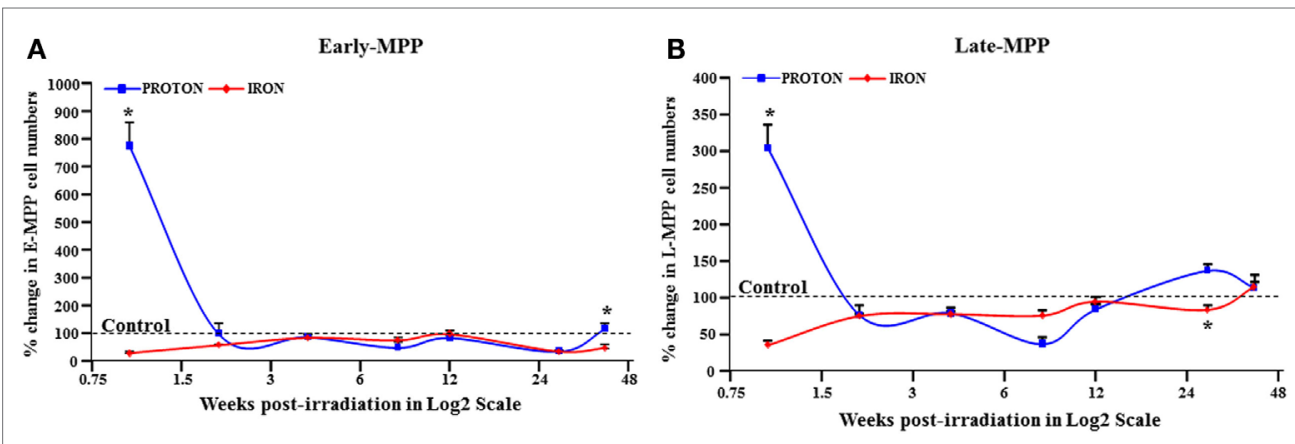

FIGURE 1 | E-MPP and L-MPP cell numbers are downregulated by ${ }^{56} \mathrm{Fe}$ - and ${ }^{1} \mathrm{H}-\mathrm{IR}$ but recover to control levels by 40 weeks post-IR. Effect of full-body single dose of proton $\left({ }^{1} \mathrm{H}\right)$ at $0.5 \mathrm{~Gy}, 1 \mathrm{GeV}$ and iron ( $\left.{ }^{56} \mathrm{Fe}\right)$ at $0.15 \mathrm{~Gy}, 1 \mathrm{GeV} /$ nucleon of ionizing radiation (IR) on survival of multipotent progenitor cell populations was examined. The survival of (A) E-MPPs and (B) L-MPPs in the BM after particle IR in C57BL/6NT mice were determined at 1, 2, 4, 8, 12, 28, and 40 weeks post-IR. Total BM-derived mononuclear cells were triple-stained with FITC-labeled RAM34 antibody (that consists of CD34, c-kit, and Sca1 antibodies), PE-Cy7-AC133, and PE-hematopoietic lineage cocktail (CD3e, Ly-6G/ Ly-6C, CD11b, CD45R/B220, TER-119), then sorted by FASC for (A) E-MPPs (CD34+/C-kit+/Sca-1+/AC133+/Lin-) and (B) L-MPPs (CD34+/C-kit $/$ Sca-1+/AC133-/Lin $\left.{ }^{-}\right)$. Percentage changes in cell numbers were calculated relative to control sham irradiated mice, which was set to $100 \%$ for each time point. Solid lines represent mean \pm SEM ( $n=6 / g r o u p)$ for ${ }^{1} \mathrm{H}-\mathrm{IR}$ (solid blue lines) and ${ }^{56} \mathrm{Fe}-\mathrm{IR}$ (solid red lines). "*” represents statistically significant differences compared to control with $p<0.05$. 
Conflict of Interest Statement: The authors declare that the research was conducted in the absence of any commercial or financial relationships that could be construed as a potential conflict of interest.

Copyright (C) 2015 Muralidharan, Sasi, Zuriaga, Hirschi, Porada, Coleman, Walsh, Yan and Goukassian. This is an open-access article distributed under the terms of the Creative Commons Attribution License (CC BY). The use, distribution or reproduction in other forums is permitted, provided the original author(s) or licensor are credited and that the original publication in this journal is cited, in accordance with accepted academic practice. No use, distribution or reproduction is permitted which does not comply with these terms. 